\title{
O FANTÁSTICO DE CHARLES NODIER: LENDA E MITO
}

\section{CHARLES NODIER FANTASTIC: LEGEND AND MYTH}

\author{
Ana Luiza Silva CAMARANI \\ Paulo Sérgio MARQUES
}

RESUMO: 0 artigo centra-se na análise do conto de Charles Nodier, "La légende de soeur Béatrix", sob a perspectiva do fantástico literário; na criação de seu texto ficcional, o autor parte de uma lenda hagiográfica que acaba por mesclar-se a mitos antigos, associando o mito mariano ao da deusa grega Perséfone. Metáfora da poesia e da musa que caminha entre os dois mitos, a personagem do conto, irmã Béatrix, mostra que a encarnação é o caminho para o reavivamento do mito e da poesia.

Palavras-chave: Narrativa fantástica. Antropologia do Imaginário. Mito. Romantismo. Literatura Francesa.

ABSTRACT: This article is focused on the analysis of Charles Nodier short story, "La légende de soeur Béatrix", from the viewpoint of the literary fantastic. In the creation of his fictional text, the author starts from a hagiographic legend which joins with ancient myths, associating the marian myth with the Greek goddess Persephone. 
The short story character who is a metaphor of the poetry and of the muse who walks between both myths, sister Béatrix shows that incarnation is the way to revive the myth and the poetry.

Key words: Fantastic narrative. Imaginary anthropology. Myth. Romanticism. French Literature.

\section{O maravilhoso cristão}

As primeiras páginas do conto de Charles Nodier (1961), "La légende de soeur Béatrix", apresentam uma discussão confrontando textos mitológicos clássicos com narrativas que se originam de lendas e contos populares nacionais. Na verdade, Nodier traz ao leitor ecos da antiga Querela dos Antigos e dos Modernos, que se desenvolveu na França do final do século XVII, isto é, no século do classicismo francês em que a Antiguidade Clássica era tomada como modelo. A controvérsia visava a determinar a superioridade, de um lado, dos artistas que seguiam os modelos antigos, e de outro, daqueles que manifestavam o espírito do progresso (acreditando, pois, na evolução da literatura) e reivindicavam o direito de inovação e criação artística.

A disputa inicia-se justamente com a questão do maravilhoso: a querela do "maravilhoso cristão" em oposição ao "maravilhoso pagão", debate estético em que os artistas denominados Modernos pretendem destituir o maravilhoso antigo em favor do maravilhoso nacional e cristão.

Essas oposições ressoam no conto de Nodier (1961, p. 781), quando o narrador principia:

Il était bien convenu en France, il y a une vingtaine d'années, que [...] toute idée qui n'avait pas passé à la filière éternelle des Grecs et des Romains, était réputée barbare. [...] La patiente admiration des collèges ne se lassait jamais de ces beaux mythes qui ne disaient pas la moindre chose à l'esprit et au coeur, mais qui flattaient l'oreille de sons épurés à la douce euphonie des Hellènes. 
Nodier (1961, p. 782) indica que, entretanto, a civilização de sua época não mais se assemelha, há muitos anos, àquela que fora nutrida, durante séculos, com as fábulas pueris do paganismo. Isso porque uma poesia, mais apropriada às necessidades do cristianismo, com ele nascera, apresentando também seus próprios mitos e histórias. Pergunta-se, então, por que essa nova fonte de inspirações maravilhosas e de ternas emoções fora negligenciada pelos escritores. Por que a lenda devota e comovente fora relegada aos serões das senhoras idosas e das crianças, como algo indigno de suprir o lazer de mentes e públicos selecionados? Tanto que,

pour en retrouver de faibles vestiges, il faut feuilleter les vieux livres qui ont été écrits par des hommes simples, ou s'asseoir dans quelque village écarté, au coin du foyer des bonnes gens. C'est là que se retrouvent de touchantes et magnifiques traditions dont personne ne s'est jamais avisé de contester l'autorité, et qui passent de génération en génération, comme un pieux héritage, sur la parole infaillible et respectée des vieillards. [...] Hâtons-nous d'écouter les délicieuses histoires du peuple, avant qu'il les ait oubliées [...]. (NODIER, 1961, p. 783-4)

Com essas palavras e por meio da voz de um narrador, Nodier (1961, p. 784) coloca a história que vai contar sob o signo da lenda popular. Logo em seguida, porém, o narrador - no papel de contador de histórias -, assinala que retirou o que vai relatar da obra de um velho hagiógrafo chamado Bzovius, continuador pouco conhecido de Baronius, este também não muito conhecido. Com efeito, Caesar Baronius (1538-1607) compôs, de 1588 a 1593, os Annales ecclesiastici, que reúnem toda a história do cristianismo desde os primeiros tempos até 1198, e Abraham Bzovius (1567-1637) continuou o trabalho de Baronius, abarcando o período de 1198 a 1571. Assim, "La légende de soeur Béatrix", escrita em 1837, apresenta-se como uma narrativa mista de lenda popular e lenda hagiográfica. 
CAMARINI, A. L. S.; MARQUES, P. S. 0 fantástico de Charles Nodier: lenda e mito

\section{A lenda}

A lenda conta que, na noite da comemoração da Anunciação do ano de 1400, alguns pastores foram atraídos por uma luz brilhante no meio de um arbusto de espinhos; quando se aproximaram, ali descobriram uma estátua da Virgem Maria segurando o menino Jesus nos braços. A réplica dessa imagem pode ser vista no interior da basílica construída para abrigar a figura original, Notre Dame de L'Épine; situada em uma pequena cidade do Marne, logo se tornou um local de peregrinação que perdura até os dias de hoje.

Nodier parte dessa lenda para construir sua narrativa, alterando certos dados de acordo com as exigências da ficção. Desloca o episódio para as montanhas do Jura, onde se situa um pequeno castelo, habitado pela viúva de um cavaleiro cristão, conhecida pela alcunha de A Santa, devido à sua dedicação aos menos afortunados e a seus hábitos caridosos. É ela quem, em um de seus passeios solitários pelas alamedas do castelo, se depara com um arbusto de espinhos carregado de flores em pleno inverno. Maravilhada, destaca um ramo florido para oferecer à imagem da Virgem que venera em seu oratório desde a infância. Um dia em que se demora no trabalho junto dos pobres e doentes, é surpreendida pelas sombras da noite e, mais adiante, por uma luminosidade fulgurante; ao constatar que a luz provinha dos arbustos de espinhos, todos completamente floridos, sente a necessidade de penetrar no âmago desse mistério, e volta ao local na noite seguinte acompanhada de um criado fiel e do capelão:

La douce lumière y régnait ainsi que la veille, et semblait devenir, à mesure qu'ils approchaient, plus vive et plus rayonnante. Ils s'arrêtèrent alors, et se mirent à genoux, parce qu'il leur sembla que cette lumière venait du ciel; après quoi le bon prêtre se leva seul, fit quelques pas respectueux vers les épines fleuries, en chantant une hymne de l'église, et les détourna sans efforts, car elles s'ouvrirent comme un voile. Le spectacle qui s'offrit en ce moment à leurs regards les frappa d'une telle admiration, qu'ils restèrent longtemps immobiles, tout pénétrés de reconnaissance et de joie. 
C'était une image de la sainte Vierge, taillée avec simplicité dans un bois grossier, animée des couleurs de la vie par un pinceau peu savant, et revêtue d'habits qui ne révélaient qu'un luxe naï; mais c'était d'elle qu'émanait la splendeur miraculeuse dont ces lieux étaient éclairés. "Je vous salue, Marie, pleine de grâces», dit enfin le chapelain prosterné [...]. (NODIER, 1961, p. 786)

O narrador diz apoiar-se nas crônicas da província para relatar esses fatos, depois de ter assinalado a tentativa vã da castelã de conservar a imagem no interior suntuoso do castelo, sempre reencontrada no meio das flores dos arbustos espinhosos; um templo é, então, construído ao redor da imagem e as notícias dos milagres da Virgem Maria propagamse pelo mundo cristão.

Dois séculos depois, irmã Béatrix, descendente da antiga castelã, torna-se a responsável pelos cuidados para com a imagem da Virgem, no templo então denominado Notre-Dame-des-Épines-Fleuries.

\section{0 fantástico}

A posição privilegiada de Nodier no cenário inicial do Romantismo francês, que se destaca como escritor, crítico, teórico, linguista, bibliófilo, permite que seja um dos primeiros escritores a refletir sobre os novos gêneros, inclusive o fantástico, tratando-os como novas modalidades para a expressão da sensibilidade de uma época: "j'étais seul, dans ma jeunesse, à pressentir l'infaillible avènement d'une littérature nouvelle", diz ele no segundo Prefácio de Smarra, publicado em 1832 (NODIER, 1961, p.37). A seu ver, a tendência ao fantástico faz parte da sociedade e da literatura de seu tempo.

No ensaio de 1830, intitulado "Du Fantastique en littérature", Nodier dedica-se a uma espécie de história literária sobre manifestações fantásticas na literatura, para chegar aos textos produzidos no Romantismo europeu. Após discorrer sobre o maravilhoso da Antiguidade Clássica e da Idade Média, assinala que 
Le fantastique demande à la vérité une virginité d'imagination et des croyances qui manque aux littératures secondaires, et qui ne se reproduit chez elle qu'à la suite de ces révolutions dont le passage renouvelle tout [...]. L'apparition des fables recommence au moment où finit l'empire de ces vérités réelles ou convenues qui prêtent un reste d'âme au mécanisme usé de la civilisation. Voilà ce qui a rendu le fantastique si populaire en Europe depuis quelques années, et ce qui en fait la seule littérature essentielle de l'âge de décadence ou de transition où nous sommes parvenus. (NODIER, 1970, p. 122-3).

Considera, assim, que as ficções fantásticas respondem aos anseios de um público posterior à Revolução Francesa, fatigado por séculos de racionalismo e ávido por toda a espécie de sensações e sentimentos:

Il ne faut donc pas tant crier contre le romantique et contre le fantastique. Ces innovations prétendues sont l'expression inévitable des périodes extrêmes de la vie politique des nations, et sans elles, je sais à peine ce qui nous resterait aujourd'hui de l'instinct moral et intellectuel de l'humanité. (NODIER, 1970, p. 123).

As ideias de Nodier sobre o fantástico espalham-se também nos prefácios e mesmo no interior de algumas de suas narrativas fantásticas. No início de "Histoire d'Hélène Gillet", publicado no mesmo ano que o segundo prefácio de Smarra, Nodier (1961, p. 330) desenvolve sua teoria sobre o fantástico, prevenindo de que "ce genre exige plus de bon sens et d'art qu'on ne l'imagine ordinairement". Passa, então, a discorrer sobre os tipos de fantástico:

Il y a l'histoire fantastique fausse, dont le charme résulte de la double crédulité du conteur et de l'auditoire, comme les Contes de fées de Perrault, le chef d'oeuvre trop dédaigné du siècle des chefs d'oeuvre. Il y a l'histoire fantastique vague, qui laisse l'âme suspendue dans un doute rêveur et mélancolique, l'endort comme une mélodie, et la berce comme un rêve. Il y a l'histoire fantastique vraie, qui est la première de toutes, parce qu'elle ébranle profondément le coeur sans coûter de sacrifices à la rai- 
son; et j'entends par l'histoire fantastique vraie, car une pareille alliance de mots vaut bien la peine d'être expliquée, la relation d'un fait tenu pour matériellement impossible qui s'est cependant accompli à la connaissance de tout le monde. (NODIER, 1961, p. 330-1).

Detendo a atenção sobre esses três tipos de fantástico assinalados por Nodier, seria possível afirmar que ele propõe, de modo ainda tênue, fundamentos teóricos dos quais a teoria de Todorov (1975, p. 50) estaria bastante próxima, quando este, considerando o maravilhoso e o estranho como dois gêneros vizinhos do fantástico, aponta a existência de gêneros transitórios ou subgêneros: o fantástico-puro corresponderia ao segundo tipo apresentado por Nodier, no qual a hesitação se mantém, deixando "a alma suspensa na dúvida"; o fantástico-estranho seria aquele que apresenta uma explicação racional, passível de ocorrer na vida real; e o fantástico-maravilhoso, no qual a existência do sobrenatural não é contestada mesmo que se oponha à realidade cotidiana.

Inspirado em uma lenda hagiográfica, o conto "La légende de soeur Béatrix" apresenta dois milagres, isto é, dois eventos que se distanciam da vida real: o primeiro, bem próximo da lenda veiculada oralmente e mais tarde recolhida por Bzovius nos Annales ecclesiastici, refere-se à imagem da Virgem Maria encontrada no meio de arbustos espinhosos de onde emana uma luminosidade resplandecente; o segundo aparece já ligado à protagonista cujo nome aparece no título da narrativa e conduz o texto ficcional para o fantástico.

No artigo intitulado "Le fantastique entre l'oral et l'écrit", Molino (1980, p. 34) defende a ideia de que o fantástico escrito deriva da lenda oral, pois a lenda aparece como a experiência autêntica da irrupção, situada no real, do excepcional ou do sobrenatural, susceptíveis de provocar a surpresa, a inquietude ou o medo.

Segundo Molino (1980, p. 33) a lenda hagiográfica distingue-se por um traço específico: está ligada ao sistema religioso ortodoxo dominante, ao mesmo tempo em que veicula motivos e temas que possam perten- 
cer a outros gêneros. A lenda popular, por sua vez, é sempre considerada como remetendo a uma experiência ou um acontecimento que realmente ocorreu, logo, é passível de credibilidade; além disso, a lenda está situada em um tempo e um espaço definidos, nos quais se apresentam seres dotados de uma identidade pessoal consistente: as três dimensões da dêixis (ego, hic, nunc) estão presentes; a lenda apresenta, ainda, a irrupção do excepcional ou do sobrenatural no real: há distinção e ruptura entre os dois domínios.

Este último traço constitui uma das características essenciais da narrativa fantástica escrita, apontado pelos diferentes teóricos que se dedicam ao estudo do fantástico literário. Bessière (1974, p. 56-7), por exemplo, assinala pertinentemente que o sobrenatural introduz uma segunda ordem possível no discurso realista da narrativa fantástica: o fantástico resultaria da contradição entre essas duas ordens e de sua recusa mútua e implícita.

No conto de Nodier, o enredo centrado em Béatrix é, em sua maior parte, completamente realista. A protagonista, jovem com dezoito anos, no máximo, tem uma vida reclusa desde seus quinze anos, quando se tornou a responsável pela estátua da Virgem. Na idade em que o amor costuma desabrochar, Béatrix só aprendera a amar Nossa Senhora. Até o momento em que um jovem senhor das cercanias, atacado por assassinos, é recolhido na enfermaria do templo, naquela época já transformado em convento. Enviada pelas irmãs para cuidar do jovem que agonizava, Béatrix reconhece Raymond, o amor de sua infância; a afeição renasce em ambos e a jovem acaba por ceder aos convites do rapaz, já curado, partindo secretamente do convento em sua companhia, depois de lançar-se aos pés da Nossa Senhora dos Espinhos Floridos, suplicando seu apoio:

«Ô céleste bienfaitrice de ma jeunesse ! dit-elle, ô vous que j’ai si longtemps uniquement aimée, et qui restez toujours la plus chère souveraine de mon âme, à quelque indigne partage que je vous fasse descendre ! ô Marie, divine Marie ! pourquoi m'avezvous abandonnée? Pourquoi avez-vous permis que votre Béatrix 
tombât en proie aux horribles passions de l'enfer? Vous savez, hélas! si j'ai cédé sans combats à celle qui me dévore! Aujourd'hui, c'en est fait, Marie, et c'en est fait pour jamais! Je ne vous servirai plus, car je ne suis plus digne de vous servir. J'irai cacher loin de vous l'éternel regret de ma faute, le deuil éternel de mon innocence que vous n'avez pas, vous-même, le pouvoir de me rendre.» (NODIER, 1961, p. 790-1)

A vida profana de Béatrix na sociedade desenvolve-se em festas e no esplendor do luxo:

La première année qui s'écoula depuis fut presque tout entière dans l'ivresse d'une passion satisfaite. Le monde même était pour Béatrix un spectacle nouveau, inépuisable en jouissances. L'amour multipliait autour d'elle tous les moyens de séduction qui pouvaient perpétuer son erreur et achever sa perte; elle ne sortait des rêves de la volupté que pour s'éveiller au milieu de la joie des festins, parmi les jeux des baladins et les concerts des ménestrels; sa vie était une fête insensée, où la voix sérieuse de la réflexion, étouffée par les clameurs de l'orgie, aurait essayé vainement de se faire entendre; et cependant Marie n'était pas tout à fait sortie de son souvenir. (NODIER, 1961, p. 791).

Aos poucos, percebe que Raymond não mais a ama, até o momento em que se vê abandonada; quinze anos haviam decorrido. Sem recursos, Béatrix caminha durante muito tempo, coberta pelos farrapos do antigo luxo; acaba por chegar às portas do mosteiro de Notre-Dame-des -Épines-Fleuries, onde é socorrida por uma das irmãs. É somente nesse instante que se pode observar o segundo elemento imprescindível para que uma narrativa seja considerada fantástica: a ambiguidade.

Pelas palavras da irmã que a socorreu vem a saber que a responsável pela imagem da Virgem que dá nome ao mosteiro é, há muitos anos e sem interrupção, irmã Béatrix. Aproximando-se do tabernáculo, entrevê um vulto que se ocupa da Virgem:

Peu à peu, la soeur se rapprochait d'elle en faisant sa revue ordinaire du saint lieu, rendant la flamme aux lampes éteintes, ou 
remplaçant les guirlandes de la veille par de nouvelles guirlandes. Béatrix ne pouvait en croire ses yeux. Cette soeur, c'était ellemême, non telle que l'âge, le vice et le désespoir l'avaient faite, mais telle qu'elle avait dû être aux jours innocents de sa jeunesse. Était-ce une illusion produite par le remords? Était-ce un châtiment miraculeux, anticipé sur ceux que lui réservait la malédiction céleste? Dans le doute, elle cacha sa tête dans ses mains, et la reposa immobile contre les barreaux de la grille, en balbutiant du bout des lèvres les plus tendres de ses prières d'autrefois. [...] C'était Marie, en effet. (NODIER, 1961, p. 796, grifos nossos).

A dúvida da protagonista - ou hesitação como indica Todorov (1975, p. 31) - determina a ambiguidade da narrativa, mantida neste conto por pouco tempo, uma vez que logo a seguir Béatrix constata ter a própria Virgem tomado suas feições e seu encargo. 0 texto termina com o sobrenatural devidamente comprovado, sem possibilidade de contestação, constituindo o que Nodier denomina "fantástico verdadeiro".

As alterações efetuadas por Nodier em relação à lenda compactuam também com o fantástico. 0 espaço da montanha escolhido por Nodier, as ruínas de antigos mosteiros, o castelo, os bosques e jardins que completam o local fazem parte da tradição do romance gótico que a literatura fantástica incorporou. No mesmo sentido, a imagem da Virgem encontrada pela castelã, excepcionalmente não se apresenta com o menino Jesus nos braços: como poderia, estando com a criança, a estátua animar-se e tomar o lugar de Béatrix?

\section{Motivos e temas}

Sempre asseverando a estreita ligação entre a lenda oral e o fantástico escrito, Molino (1980, p. 36) assinala a correspondência de temas entre uma e outro; "a mulher e o amor" seria um desses temas comuns, pelo fato de a mulher ser dotada de uma ambivalência que a torna tanto celestial quanto demoníaca. De fato, Béatrix, virgem devota ao sagrado, chega a uma extrema degradação pela mudança de seus valores decorrente do amor profano. 
0 motivo da flor adquire particularmente em Nodier uma importância simbólica. Observando o conjunto de sua obra, a flor sempre aparece ligada à mulher: emblema da mulher, do amor e da morte, acaba por representar a eternidade; as flores de Nodier desabrocham mesmo no além-túmulo e, muitas vezes, são representadas pelas estrelas, suas irmãs celestes. Plenas de amor ou de piedade pelos mortais, as flores que crescem no céu sacrificam algumas vezes sua habitação celeste e dirigem-se para a terra, aponta Hamenachem (1972, p. 131), referindo-se aos espinheiros cobertos de botões no rigor do inverno em "Légende de soeur Béatrix": as flores brancas, banhadas por uma luz sobrenatural, seriam portadoras de uma mensagem divina.

0 motivo da estátua e o tema do duplo, por sua vez, pertencem à tradição literária do fantástico. Mesmo considerando a relevância das reflexões de Vax (1965, p. 79 e 67), que, ao examinar motivo e tema como os dois termos de uma relação dinâmica mostra a polivalência desses elementos, vê-se que o próprio teórico admite que alguns motivos e temas são menos polivalentes do que outros e revelam-se recorrentes na literatura fantástica. É este justamente tanto o caso do motivo da estátua que cria vida, quanto o do tema do duplo decorrente da animação do que deveria permanecer inanimado.

Enfim, ao aventar a substituição dos mitos antigos pelos do cristianismo, Nodier indica o retorno ao passado nacional e sugere uma inspiração derivada do folclore medieval, isto é, propõe que seja aproveitado o legado popular, responsável por uma nova e rica mitologia.

\section{Maria e a Grande Mãe}

Esse legado é, na verdade, resultante de um longo sincretismo verificado nas formas religiosas europeias, de modo que, se Nodier, de um lado, exalta no prólogo o mito cristão contra o mito grego, de outro, a narrativa que segue reencontra o imaginário antigo pagão, por meio da vertente popular mantida pelo passado nacional. Para conciliar essa ten- 
são, é preciso traçar a evolução histórica do mito mariano na Europa.

As origens romanas do cristianismo caracterizaram-se por "vigorosas tendências ascéticas" (BARROS, 2004, p. 148), com a consequente condenação da sexualidade, da carne e da mulher. Apesar dessa tradição patriarcal e misógina do catolicismo ortodoxo, o povo jamais conseguiu se livrar da adoração às imagens da deusa, expressões particulares do culto à divindade arquetípica da Grande Mãe.

Depois da destruição do templo de Deméter, em Elêusis, a devoção confluiu para o culto mariano, que a Igreja tentou em vão reprimir, até capitular e admitir a mãe de Jesus no panteão do cristianismo. Já no início do século $\mathrm{V}$, surgem as primeiras igrejas consagradas a Maria, muitas delas em antigos santuários dedicados às deusas pagãs. Nesse sentido, é interessante lembrar que algumas das aparições da santa são atribuídas a imagens escondidas e redescobertas: quando o cristianismo proibiu o culto pagão, o povo escondia imagens em troncos de árvores e grutas; a descoberta dessas imagens, séculos mais tarde, seria interpretada como hierofania da mãe de Jesus.

Será entre os celtas, contudo, que a Virgem cristã encontrará sua horda de fiéis mais devotos. Quando a religião cristã chegou à Bretanha e à Gália, só foi aceita mediante a incorporação de elementos da religião céltica, o druidismo, que cultuava principalmente versões femininas da divindade, como as antigas religiões pré-helênicas. Ali, Maria foi revestida com as imagens das deusas pagãs que a precederam e se fortaleceu como principal veículo da religiosidade popular, até assumir a centralidade de uma nova expressão poética, espiritual e cultural:

O culto à Virgem Maria evoluiu através dos séculos, ocupando lugar de destaque no coração de todos; Maria Madalena transformou-se em santa e promoveu com isso as prostitutas arrependidas; o amor cortês, que tomou conta da França no século XII, transformou a religião do Amor na religião da Mulher. (BARROS, 2004, p. 150-151) 
O leitor atento já conseguirá rastrear alguns motivos presentes no conto de Nodier, como uma atualização romântica daqueles elementos - o culto à Virgem, a pecadora arrependida, o amor platônico à mulher. Pode-se, então, notar que o mito da Virgem servirá ao autor, nessa narrativa, para tematizar o amor e a devoção encarnados, que eclodiram no imaginário ocidental com a estética cortesã do século XII e seduziram a poética do Romantismo. 0 platonismo da patrística era uma interpretação parcial da proposta socrática. Saltava a etapa de apreensão da Beleza nos corpos e pregava a experiência direta da Beleza ideal. 0 amor cortês era platônico num sentido mais radical: só se chegava à Beleza do espírito pelo caminho do corpo. Daí a forte sensualidade da poesia trovadoresca, aparentemente em contradição com o amor idealizado. Pela mesma razão, o modelo patrístico da Virgem Maria Imaculada, proposto pelo catolicismo ortodoxo, será substituído, nos ritos da Provença, pelo de outra Maria, a pecadora arrependida Madalena.

Como novo avatar do arquétipo da Grande Mãe, Maria, associada a Madalena, continua, pois, a linhagem das deusas antigas, apresentando associações com a principal delas em terreno europeu: a Diana dos romanos. No clássico 0 ramo de ouro, James George Frazer recorda que 13 de agosto era a data da maior festa europeia consagrada à deusa pagã. "A Igreja Católica parece ter santificado essa grande festa da deusa virgem, transformando-a de maneira engenhosa na festa católica da Assunção de Nossa Senhora, a 15 de agosto", nota Frazer (1982, p. 24-25), argumentando que, segundo um texto siríaco em honra de Maria, os apóstolos haviam ordenado que se celebrasse a Mãe de Deus no dia 13 de agosto. A data reaparece no culto da Senhora de Fátima, que, revelandose a três crianças pastoras a 13 de maio, teria agendado encontro com os meninos a cada dia 13 dos meses seguintes. Em 13 de agosto ocorreria sua quarta hierofania, justamente aquela que permaneceu em mistério, pois, retidas pelas autoridades, as crianças não puderam encontrar a santa. Considerando-se o conto de Nodier, as coincidências de datas não param, porém: 12 de agosto é dia consagrado a Santa Beatriz, fundadora 
lendária - também portuguesa - do primeiro mosteiro dedicado a Nossa Senhora da Imaculada Conceição.

A pureza e brancuras típicas dos atributos marianos estão presentes em Nodier e também associam a divindade cristã às pagãs. Além das flores brancas, a aparição de Notre-Dames-des-Épines-Fleuries conjuga outras imagens da alvura: a Virgem é precedida pela visão de "la douce lumière", "une clarté calme et pure" que lembrava "des myriades de vers luisants" (NODIER, 1961, p. 786). Estudioso das aparições marianas, Palacios Tapias (1995, p. 33) lembra que a luminosidade que acompanha a Virgem cristã é o principal atributo de Diana e herança da divindade da aurora, a Filha do Céu que abre as portas do dia e, por decorrência, de todas as graças, e ganhou atenção de Robert Graves, que lhe dedicou todo um livro, A Deusa Branca (2003).

\section{Perséfone e os mistérios do renascimento}

Diana, por sua vez, era confundida com Perséfone, a filha de Deméter, em alguns lugares da Arcádia (BRANDÃO, 1986, p. 284). Um dos principais traços de identidade entre as duas deusas era a castidade. Segundo Jung (2000, p. 92), a Deusa Virgem é expressão da "mãe rejuvenescida", o que a associa a Perséfone, cujo nome mais difundido era Coré, que significa "A Jovem".

0 mito da deusa conta que, dotada de beleza ímpar, ela motivou incontrolável paixão em Hades, deus do Inferno, que a sequestrou enquanto ela colhia flores, sua atividade preferida. Depois de uma estada no Inferno, conseguiu retornar ao Olimpo, onde sua mãe obteve do conselho de deuses que ela passasse dois terços do ano em sua companhia; o outro terço seria tributado ao marido e vivido nas sombras infernais.

Perséfone era a figura central dos Mistérios de Elêusis, religião que perdurou na Grécia por mais de dois mil anos. Naqueles mistérios, que eram dedicados ao culto da tríade Deméter-Perséfone-Dioniso, Deméter, a deusa nutriz da agricultura, é "o caminho para a luz, o archote que 
ilumina o caminho", enquanto sua filha, Perséfone, é "o grão que morre para renascer mais jovem, forte e belo" (BRANDÃO, 1986, p. 304) e simboliza, portanto, o neófito, que morre para renascer numa vida superior. Daí o epíteto da deusa, Coré, a Jovem.

A função de Perséfone, no mito grego, é a mesma que Maria passa a assumir após a sua consagração. Como passava um terço do ano no mundo dos mortos, Perséfone estabelece uma ponte com o Olimpo e pode, então, "intervir no destino dos homens mortais" (BRANDÃO, 2008, p. 275). A sagração da mãe de Jesus pela religião católica aproximou-a, assim, ainda mais da divindade pagã: subida ao Céu, Maria passa a ser igualmente a intercessora divina das criaturas terrenas e carnais no ambiente divino. Essa humanização da divindade faz renascer, no cristianismo, o caráter dos deuses helênicos, cujo antropomorfismo lhes confere a função de estabelecer vínculos entre a essência divina e a humana, reunindo espírito e matéria, razão e sentimento, ideia e fenômeno. Por meio da história desses deuses e deusas, mostrava-se que, no humano, "o corpo manifestava seus dons ao avivar a conduta por meio da paixão." (ROBLES, 2006, p. 68).

0 mito de Perséfone representa, portanto, o movimento de queda e ascensão que serve de modelo à divinização do humano. Ele fala "da natureza da perda, da dor e da separação", de modo que "Elêusis expressa o mistério da separação e do encontro renovado." (MONTEIRO, 1998, p. 144-145). Vemos, então, que o itinerário da irmã Béatrix é uma expressão literária daquele mito, que os símbolos que aparecem no conto, como a Virgem dos Espinheiros Floridos, atualizam e reavivam.

0 ciclo empreendido pela irmã Béatrix compõe um rito de passagem, por meio de cujos sofrimentos a personagem chega a um grau mais elevado de espiritualidade. Essa elevação só pode ser obtida pela ação de uma força iniciadora, que, no mito, cabe à Senhora do Inferno:

Perséfone significa "aquela que traz desalento". Em Atenas, também era conhecida como Parsaffata, que significa "aquela que traz a destruição". Com esse mesmo simbolismo passaria 
ao acervo mitológico dos romanos, pois, para eles, Prosérpina era "a terrível" ninfa que durante os ritos realizava sacrifícios ao deus sagrado. (ROBLES, 2006, p. 72).

Béatrix atualiza a jornada da deusa, vivendo sua própria queda e posterior glorificação. Levada, também por um homem, da companhia de sua mãe divina, a jovem freira provará dos apelos da carne antes de receber a graça da "imortalidade”. Nas antigas civilizações agrárias, o rapto simbolizava o sepultamento da semente para renascer na espiga. Em termos psicossociais, Paul Diel (1991, p. 187) interpreta o rapto de Perséfone como a captura do indivíduo pelo desejo terrestre e seu retorno ao Olimpo como a sublimação desse desejo, exatamente como ocorre no trajeto da irmã Béatrix, cujo ascetismo inicial soava algo artificial, forçado e não voluntário.

Aqui também a personagem recupera o cristianismo de raízes célticas. Os druidas viviam sua religiosidade isolando-se em lugares ermos, como o alto de montanhas (BARROS, 2004, p. 126-127). Por isso, o cristianismo céltico se expressará principalmente na vida monástica, como aquela retratada no conto de Nodier. A igreja e o mosteiro de Notre-Dame-des-Épines-Fleuries prolongam a preferência por esses espaços inóspitos, situando-se “à l'extrémité d'une gorge étroite et profonde" (NODIER, 1961, 785), “dans ces solitudes à plus de cinq lieues à la ronde"(NODIER, 1961, 794).

Fundado na tradição céltica, o espírito monástico herda igualmente a principal característica de um religioso druida, o heroísmo: para esse homem, a bem-aventurança não é inata, mas deve ser o resultado de uma jornada de dor (BARROS, 2004, p. 134). Do mesmo modo, o Paraíso desse povo não era apenas um reino de paz, mas também um lugar de amor e prazeres carnais (BARROS, 2004, p. 138). Daí a necessidade do sacrifício para se atingir a beatitude celeste. 


\section{O Inferno de irmã Béatrix}

Béatrix pertence a uma linhagem de mulheres consagradas: descende d'A Santa, uma viúva sem herdeiros, inteiramente dedicada, como a donzela, à guarda de Maria, o modelo da consagração feminina. Como Perséfone, é "a filha apenas ligada à mãe" (MONTEIRO, 1998, p. 145).

Outra qualidade que as irmana é o mundo vegetal em que orbitam. Se a principal ocupação e alegria de Béatrix é colher flores para o altar da Virgem, Perséfone é a deusa que colhe flores e foi durante essa atividade que foi raptada por Hades.

Também a versão mariana explorada no conto de Nodier é uma divindade da vegetação, que aparece em um espinheiro florido e recebe, como principal oferenda, ramos, buquês e guirlandas. Sua flor "preferida", contudo, é a do espinheiro (NODIER, 1961, 788). As flores do mosteiro de Notre-Dame-des-Épines-Fleuries são "belles petites étoiles blanches à rayons incarnats" (NODIER, 1961, 785), lembrando, na forma, os cravos e o sangue, imagens do sofrimento. Nascem de espinheiros, num "parterre sauvage" (NODIER, 1961, 786). 0 espinho é um dos símbolos associados às aparições marianas e representa a dor, o sacrifício e o ascetismo. Conforme Palacios Tapias (1995, p. 156), “ele sugere o ermo deserto do retiro do solitário, a terra bárbara, virginal, não cultivada pelo homem e destina ao refúgio, à liberdade e à luta dos animais mais selvagens, silvestres, fugitivos [...]. É nessa terra vazia onde a Virgem Maria prefere sediar as suas aparições". Presente na coroa de Cristo, simboliza aquele que traz a morte contra si mesmo e também inspira os que se entregam ao casamento, “o caminho da 'felicidade' profana”. Os espinhos da Virgem, que continuam como espinhos de Béatrix, apontam, então, para o caminho de dores que a moça deverá experimentar para merecer a companhia divina.

A personagem de Nodier compartilha até a mesma psique com a filha de Deméter. 0 mito de Perséfone simboliza, na psicologia analítica, o que Jung (2000, p. 98-99) nomeia de complexo materno de "identificação 
com a mãe". Trata-se daquele modelo de comportamento em que a filha se identifica de tal forma com a figura materna, que nega a própria vida erótica e passa a viver como "sombra" ou espectro, numa cadeia fechada de amor recíproco entre as duas mulheres, do mesmo modo como vemos na relação da personagem de Nodier com sua mãe divina: "La sainte Vierge aimait Béatrix et se plaisait à en être aimée. Elle avait lu d'ailleurs peut-être dans le coeur de Béatrix qu'elle en serait aimée toujours." (NODIER, 1961, p. 789). Qualquer erotismo só pode ser, então, desencadeado na forma de um rapto. Na esteira de Jung, sobre a vida interior simbolizada por Perséfone, Monteiro (1998, p. 146) afirma que, "até mesmo quando sabe seus motivos e desejos, ela os sente e até os concretiza, mas dificilmente consegue explicar suas razões logicamente". À semelhança de Béatrix, que se entrega sem censura à vontade de seu raptor, Perséfone "vive a sutil dissolução do ser, quase como um estado de fusão com o outro" (MONTEIRO, 1988, p. 147); maleável e sem uma vontade forte, "junto do homem torna-se o que ele deseja." (MONTEIRO, 1988, p. 147). Jung (2000, p. 99) observa que "ela é de tal forma um apêndice da mãe que já não sabe o que lhe acontece quando um homem aparece por perto". Assim, a irmã Béatrix também "n'avait pu trouver des expressions pour rendre ce qu'elle éprouvait." (NODIER, 1961, p. 790), ela estranha e desconhece as emoções que a assaltam. Diante da surpresa, prefere primeiramente agarrar-se ainda mais à mãe divina:

Incapable de s'expliquer alors les mouvements secrets dont elle était agitée, elle les avait pris pour l'instinct d'une pieuse ferveur qui s'accuse de n'être pas assez ardente [...] L'objet inconnu de ces transports échappait à son inexpérence; et parmi ceux qui tombaient, si l'on peut s'exprimer ainsi, sous les sens de son âme ingénue, la sainte Vierge seule lui paraissait digne de cette adoration passionnée, à laquelle sa vie pouvait à peine suffire. (NODIER, 1961, p. 788)

Como Hades retirou Perséfone de sua existência imaculada no seio da mãe, a partida de Béatrix também é anunciada como um rapto. Nos dois 
casos, o rapto simboliza a irrupção do elemento masculino na vida da mulher, que a leva a conhecer o amor e os prazeres terrenos e, com isso, uma espécie de morte de sua pureza feminina. “Coré [...], após a descida, não será mais a mesma, uma parte dela morre. Terá a partir desta relação um conhecimento mais pleno de si, com mais profundidade" (MONTEIRO, 1998, p. 144). Assim, o conto de Nodier repete o mito:

Béatrix se leva, s'approcha, tremblante, de l'image de la sainte Vierge, la para de nouvelles fleurs, se saisit de celles qu'elle venait de remplacer, et, honteuse pour la première fois de l'usage pieux qu'elle n'avait plus le droit d'en faire, elle les pressa sur son coeur, dans le sachet bénit du scapulaire, pour ne jamais s'en séparer. Après cela, elle jeta un dernier regard sur le tabernacle, poussa un cri de terreur et s'enfuit.

La nuit suivante, une voiture rapide entraîna loin $d u$ couvent le beau chevalier blessé, et une jeune religieuse, infidèle à ses voeux, qui l'accompagnait. (NODIER, 1961, p. 791).

Em comparação com o andamento lento do parágrafo anterior, em que a moça recolhe o ramo, o fechamento rápido da cena, no segundo parágrafo, sugere uma fuga, um amor interdito. Também sucede, como no caso de Perséfone, à colheita de uma flor, cuja marcescência, no conto, antecipa o "inferno" que se abaterá sobre a ex-freira. À frente, o narrador vai falar dessas flores que "s'etaient flétries comme celles du bonheur." (NODIER, 1961, p. 792). Note-se que Béatrix não aparece na narrativa do último parágrafo; sua presença é apenas pressentida naquela carruagem que parte apressada. Assim, a irmã Béatrix repete, no entrecho, os mesmos gestos da donzela do mito: colhe a flor, grita e desaparece.

Perséfone é Rainha do Inferno, deusa dos mortos, das sombras e fantasmas. Goza, portanto, de "uma certa insubstancialidade" que torna sua presença ambígua: “Está presente e não está”, afirma dela Monteiro (1998, p. 147), como podemos afirmar da irmã Béatrix, que pode, ao mesmo tempo, percorrer o mundo e guardar a capela da santa. Essa juventude imortalizada parece-nos o principal traço a reunir a personagem de Nodier 
à deusa Perséfone. Como sabemos, Coré é aquela que guarda o segredo da eterna juventude - Afrodite enviou Psiquê ao Inferno para arrebatar a maquiagem da temida deusa, que tinha o poder mágico de manter seu usuário sempre jovem. Depois de passar por "une vieillesse hâtive" (NODIER, 1961, p. 793), irmã Béatrix recebe a graça de conservar o frescor da juventude: "La bonté divine a permis qu'elle ne perdît pas en vieillisant une des grâces de sa jeunesse." (NODIER, 1961, p. 795-6). A partir de então, "toute l'existence de Béatrix s'écoula comme un seul jour", de modo que ela passa a viver como que num tempo circular e eterno: "Elle vécut un siècle sans avoir paru vieillir". Mesmo sua morte é descrita na forma eufêmica dos que se entregam à bondade da Grande Mãe Perséfone: "Béatrix mourut cependant, ou plutôt elle s'endormit avec calme dans ce sommeil passager du tombeau qui separe le temps de l'éternité." (NODIER, 1961, p. 798). Lembremo-nos, finalmente, de que os arbustos do mosteiro revelam a mesma juventude eterna, pois não são afetados pela mudança das estações e "fleurissent toujours" (NODIER, 1961, p. 795).

0 perdão da irmã Béatrix e sua glorificação não se devem apenas à misericórdia mariana, mas é o reconhecimento da necessidade da encarnação e do sacrifício para se elevar à glória espiritual. "Descer ao Hades e casar-se com a morte é um sacrifício, isto é, um tornar sacro, uma iniciação." (MONTEIRO, 1998, p. 150, grifo da autora). Esse destino de Béatrix já está anunciado na ambiguidade da idade de transição da jovem, dita pelo narrador como "feliz ou funesta" (NODIER, 1961, p. 788) e vivida pela moça como uma hesitação entre a virtude e o pecado, a "prece" e a "blasfêmia" (NODIER, 1961, p. 790). Trata-se de um sacrifício, que é aceito voluntariamente, pelo benefício que o mal pode trazer. Por isso, no caso de Béatrix, "l'infortunée accepta sa damnation." (NODIER, 1961, p. 792).

A vida que segue será sua catábase, a descida ao Inferno: "son voyage semblait ne devoir aboutir qu'à la mort.” (NODIER, p. 1961, p. 793). Aqui, por meio da identificação com a Deusa do Inferno, Béatrix chega à figura cristã da prostituta sagrada, uma “brebis égarrée” (NODIER, 1961, p. 
794), a Madalena cultuada pelos hereges da Provença.

Conforme Maria Nazareth Alvim de Barros, estudiosa do imaginário sobre a mulher no Ocidente, Madalena é uma figura feminina de síntese de contrários, a impureza que conduz à consagração e à bênção, reunindo as duas pontas do mito bíblico, Eva e Maria, a mulher diabólica e a mulher celestial. Cria, com isso, um espaço intermediário entre Inferno e Céu, o Purgatório, região de fronteira, por intermédio do qual o pecador se eleva à santidade. Essa é a jornada empreendida por Béatrix, que só poderá alcançar a glória final depois da queda: "Elle demeura seule, délaissée, objet de mépris pour les autres comme pour elle-même, livrée aux dédais insolents du vice, et odieuse à la vertu, exemple rebutant de honte et de misère que les mères montraient à leurs enfants pour les détourner $d u$ péché !" (NODIER, p. 1961, p. 792). Seu retorno inconsciente ao mosteiro atesta a simetria de sua jornada com o lugar inóspito da Virgem à qual foi consagrada:

Un jour [...], elle avait parcouru [...], sur le revers d'une montagne nue, un sentier âpre et raboteux, sans que l'aspect d'aucune maison vint consoler sa lassitude; elle avoit eu pour seul aliment quelques racines sans saveur arrachées aux fentes des rochers; sa chaussure en lambeaux venoit d'abandonner ses pieds sanglants; elle se sentait défaillir de fatigue et de besoin. (NODIER, 1961, p. 793, grifos nossos).

0 cuidado dispensado pela irmã do mosteiro semelha à ressurreição, simboliza o retorno de Béatrix-Perséfone ao seio materno da bondosa nutriz Maria/Deméter:

"Fortifiez-vous de ce bouillon que j'ai chauffé à la hâte, aussitôt que je vous ai aperçue; goûtez ce vin généreux qui rendra la chaleur à votre estomac et la souplesse à vos membres endoloris. Faites-moi signe que vous êtes mieux. [...] Donnez-moi entre mes mains vos petites mains si froides, pour que j'y rappelle le sang et la vie. Sentez-vous déjà vos doigts se dégourdir sous mon haleine? Oh! vous serez bien tout à l'heure!" (NODIER, 1961, p. 794, grifos nossos). 
O retorno de irmã Béatrix ao mosteiro ocorre justamente no dia da Assunção, 15 de agosto, festa pagã de Diana-Perséfone. Como a recordar a antiga Mãe, dessa vez os festejos se realizam, no mosteiro, "dans um mélange de recueillement et d'extase" (NODIER, 1961, p. 797). A antítese entre resguardo e êxtase resume o trajeto de Béatrix e informa que só se pode glorificar o que se perdeu e foi encontrado, a subida ao céu só se projeta depois de uma queda. Por isso, com o retorno de Béatrix,

par un phénomène étranger à cette saison, toutes les épines de la contrée avaient refleuri, de sorte que ce n'était, au dehors comme au dedans, que printemps et parfums. C'est qu'une âme était rentrée dans le sein du Seigneur, dépouillée de toutes les infirmités et de toutes les ignominies de notre condition, et qu'il n'y a point de fête qui soit plus agréable aux saints. (NODIER, 1961, p. 797, grifos nossos).

Para retornar, foi preciso partir; sem o pecado, não há motivo para exercer a misericórdia. Esse é o mistério do iniciado em Elêusis, que inspirou os cátaros, serviu ao fino raciocínio de Gregório de Matos para argumentar o perdão divino e surgiu em Nodier como a missão da arte que se quer renovar.

\section{Beatriz e os mistérios da inspiração}

Senhora da morte e do renascimento, ou seja, da perpétua recriação, Perséfone "encarna o brotar, o novo, a graça - enquanto ritmo - e a beleza - enquanto proporção" (MONTEIRO, 1998, p. 145) e, por essa via, aproxima-se das divindades que presidem as artes. Acrescentemos, aqui, que a juventude eterna é o primeiro atributo das musas e a personagem de Nodier é homônima de uma renomada musa ocidental: a Beatriz de Dante. Como a musa de Alighieri, conservada na frescura de sua juventude pela poesia do florentino, esta Béatrix também será preservada do envelhecimento pela Virgem patrona da devoção cortesã, o que nos permite compreendê-la também como uma expressão simbólica da 
atividade poética, tema justamente do prólogo de Nodier a essa "lenda".

Vimos que, ao contrário da Maria "imaculada" e asséptica proposta pelas autoridades eclesiásticas, a versão mariana proposta pela narrativa de Nodier recupera a ambiguidade da deusa pagã, típica da cultura popular, que vê na deusa uma combinação de propriedades contraditórias. Jung (2000, p. 92-93) limita essas propriedades em três atributos centrais: bondade, expressa na nutrição e no cuidado; paixão, como "emocionalidade orgiástica"; e escuridão, a obscuridade subterrânea sem a qual não se ressuscita para a vida nova. A sequência de atributos da deusa mapeia, pois, a jornada da irmã Béatrix: de filha amada e amante no seio da Mãe, passa ao rapto orgiástico e desse ao derruimento e à morte, para ser finalmente retomada pela bondade materna da santa, cumprindo o ciclo necessário para o reavivamento do mundo e dos seres. Joseph Campbell (2004, p. 36-38) dispõe a tríade figurando-a em "três ninfas" presentes na Odisseia: a generosa Calipso; a sedutora, sombria e mortal Circe; e a inocente virgem Nausícaa. Vemos a trindade expressa na combinação de personagens em Nodier: Maria, Béatrix-Madalena-Perséfone e Beatriz-Musa.

Empregando-se a terminologia de Lévi-Strauss (p. 243-244), que cunhou o termo mitema para nomear esse "feixe de relações" que estrutura os mitos, pode-se afirmar que o conto de Nodier apresenta, então, um complexo mitema que entrelaça três mitos femininos ocidentais: Maria, Perséfone e Beatriz, sistema triádico em que o mito mariano é o elemento mediador entre os outros dois.

Se tomarmos o esquema de Erich Neumann (2003, p. 72) para as expressões míticas do arquétipo da Grande Mãe, verificaremos que Maria é o nome comum aos dois polos de manifestações do arquétipo materno positivo: o polo de Deméter, da "Mãe Bondosa" e dos "Mistérios da Vegetação", e o polo das Musas, do feminino transformador, que preside aos "Mistérios da Inspiração". No conto de Nodier, o mito mariano serve, portanto, para estabelecer as relações entre os dois polos e fazer de Perséfone o caminho para a Musa, atualizada no nome da personagem irmã "Béatrix". 
Robert Graves já defendeu, aliás, que toda manifestação mítica da Grande Mãe, na Europa, resume uma “linguagem mágica” própria de ritos "em honra à deusa-lua ou Musa" (GRAVES, 2003, p. 12, grifo nosso), cuja permanência no imaginário europeu se deveu justamente ao mito de Perséfone:

A antiga linguagem sobreviveu com bastante pureza nos secretos cultos mistéricos de Elêusis, de Corinto, da Samotrácia e alhures. Quando esses foram proibidos pelos primeiros imperadores cristãos, ela continuou sendo ensinada nas escolas poéticas da Irlanda e de Gales, bem como nos covens de bruxas da Europa Ocidental. (GRAVES, 2003, p. 14)

Como vimos, essa tradição mantida entre os celtas ressurgirá no mito mariano, que estabelece, assim, um vínculo entre o mito cristão e o pagão, bem como entre o arquétipo feminino e a exaltação da Musa.

Campbell conta que havia uma oração, popular nos séculos XII e XIII - era da estética cortesã e mariana - que rezava: "Ó, Senhor, que ensinastes Maria a conceber sem pecar, ensinai-me a pecar sem conceber". Para Campbell, a oração expressa a presença de duas mitologias em conflito: "Uma é a de deleite numa vida considerada pecaminosa; outra, a de zelo para gerar o salvador do mundo" (CAMPBELL, 2004, p. 40). A primeira é a luxúria; a segunda, o ágape, puramente espiritual. Ambos, como nota Campbell, são "impessoais". 0 poeta romântico, sabe-se, busca a terceira via - pecar e conceber -, para a qual o caminho de acesso, como pretendemos ter demonstrado, é a jornada de queda e glorificação de Perséfone, que se reacende no mundo cristão, conforme defende Campbell, no amor cortesão da Provença e na renovação do mito mariano.

"A sublimação-espiritualização do desejo terrestre [...] é o sentido verídico da vida, a verdade da vida, o alimento do espírito", afirma Diel (1991, p. 188), comentando o ciclo de Perséfone. Se o mito desta deusa guarda o mistério da Vida, ele é então o caminho para a revitalização do próprio mito, por isso seu aproveitamento na narrativa do romântico 
Nodier: retirada de suas alturas abstratas e idealizadas do Classicismo, a poesia precisa ser reencarnada para ganhar a espiritualidade desejada pela estética romântica. Essa encarnação aparece naquela imagem proposta pelo narrador para a narrativa popular, "quand les anges et les saints pouvaient se mêler, sans trop déroger de leur grandeur céleste, à des peuples simples et purs [...]" (NODIER, 1961, 783).

Adverso à pureza dos esquemas unilaterais, o Romantismo, como já o mostraram Rosenfeld e Guinsburg (2002, p. 270), encontra sua síntese na natureza da contradição. Herdeiro do imaginário barroco, seu ideal estético encontra-se, portanto, na busca da reconciliação entre sentimento e intelecto, paixão e ascetismo, carne e espírito. Nesse sentido, é que o Romantismo faz sua opção pelo mito vivo: encarnar é o caminho para a poesia, como o foi para a irmã Béatrix, que, assim, atualiza em Nodier o papel da musa de Alighieri.

A oposição entre purismo formal (artificial) e purificação essencial (viva) já estava anunciada no prólogo dissertativo de Nodier. Ali, como vimos, ele já condenava o esvaziamento da estética superficial do mito puramente formal. Sua condenação do mito pagão decorre do reconhecimento de que "ces beaux mythes [...] ne disaient pas la moindre chose à l'esprit et au coeur" (NODIER, 1961, 781) e não se pode encontrar neles a "poésie véritable" (NODIER, 1961, 782) que pode falar aos que ainda conservam "une âme pour croire, pour sentir et pour aimer [...]" (NODIER, 1961, 783). Logo adiante, o autor vai ampliar a imagem, identificando mais diretamente essa poesia com a figura feminina em perdição: "Hâtons-nous d'écouter les délicieuses histoires du peuple, avant qu'il les ait oubliées, avant qu'il en ait rougi, et que sa chaste poésie, honteuse d'être nue, se soit couverte d'un voile comme Ève exilée du paradis."(NODIER, 1961, 784).

É importante, nesse sentido, recordar que a própria imagem da Virgem, em Nodier, reafirma uma opção pelo natural contra o artificial. Sobre o ícone da santa, conta o narrador: 
C'était une image de la sainte Vierge, taillée avec simplicité daus un bois grossier, animée des couleurs de la vie par un pinceau peu savant, et revêtue d'habits que ne révélaient qu'un luxe naïf; mais c'était d'elle qu'émanait la splendeur miraculeuse dont ces lieux étaient éclaires. [...] La bienheureuse mère de Jésus avait préféré l'ombre modeste de seus buissons favoris à l'éclat d'une demeure mondaine. (NODIER, 1961, p. 786-7).

Desse modo, o prólogo não é apenas artifício para a verossimilhança do conto, mas exposição dissertativa da metáfora narrativa que virá; não apenas relato das supostas origens da "lenda", mas anúncio do tema que ela abordará, informação sobre a matéria simbólica contida nos motivos tecidos pelo narrador.

\section{Referências}

BARROS, Maria Nazareth Alvim de. As deusas, as bruxas e a Igreja: séculos de perseguição. 2.ed. Rio de Janeiro: Record, Rosa dos Tempos, 2004.

BESSIÈRE, Irène. Le récit fantastique: la poétique de l'incertain. Paris: Larousse, 1974. (Thèmes et textes).

BRANDÃO, Junito de Souza. Dicionário mítico-etimológico. 5.ed. Petrópolis: Vozes, 2008, v.1.

. Mitologia grega. Petrópolis: Vozes, 1986, v.1.

CAMPBELL, Joseph. E por falar em mitos: conversas com Joseph Campbell entrevistado por Fraser Boa. Tradução de Marcos Malvezzi Leal. Campinas: São Paulo, 2004.

DIEL, Paul. O simbolismo na mitologia grega. Tradução de Roberto Cacuro e Marcos Martinho dos Santos. São Paulo: Attar, 1991. 
FRAZER, James George. O ramo de ouro. Tradução de Waltensir Dutra. Rio de Janeiro: Guanabara Koogan, 1982.

GRAVES, Robert. A Deusa Branca: uma gramática histórica do mito poético. Tradução de Bentto de Lima. Rio de Janeiro: Bertrand Brasil, 2003.

HAMENACHEM, Miriam, S. Charles Nodier: essai sur l'imagination mythique. Paris : Nizet, 1972.

JUNG, Carl Gustav. Os arquétipos e o inconsciente coletivo. Tradução de Maria Luíza Appy e Dora Mariana R. Ferreira da Silva. Petrópolis: Vozes, 2000.

LÉVI-STRAUSS, Claude. A estrutura dos mitos. In : Antropologia estrutural. Tradução de Chaim Samuel Katz e Eginardo Pires. 6.ed. Rio de Janeiro: Tempo Brasileiro, 2003, p. 237-265.

MOLINO, Jean. Le fantastique entre l'oral et l'écrit. Europe, Paris, n. 611, p. 32-41, mars 1980.

MONTEIRO, Dulcinéa da Mata Ribeiro. Mulher - Feminino plural: mitologia, história e psicanálise. Rio de Janeiro: Record, Rosa dos Tempos, 1998.

NEUMANN, Erich. A Grande Mãe: um estudo fenomenológico da construção feminina do inconsciente. Tradução de Fernando Pedroza de Mattos e Maria Silvia Mourão Netto. 4.ed. São Paulo: Cultrix, 2003.

NODIER, Charles. Du fantastique en littérature. In: JUIN, Hubert. Charles Nodier. Paris: Seghers, 1970. p. 119-138. . Contes. Paris: Garnier, 1961. 
PALACIOS TAPIAS, Juan-Isidro. Aparições de Maria: lenda e realidade sobre o mistério mariano. Tradução de Ricardo Aníbal Rosenbusch. 2.ed. Rio de Janeiro: Record, 1995.

ROSENFELD, Anatol; GUINSBURG, J. Romantismo e Classicismo. In: GUINSBURG, J. (org.). O Romantismo. 4.ed. São Paulo: Perspectiva, 2002.

TODOROV, Tzvetan. Introdução à literatura fantástica. Trad. M. Clara C. Castello. São Paulo: Perspectiva, 1975.

VAX, Louis. La séduction de l'étrange. Paris: PUF, 1965. (Philosophie Contemporaine). 